\title{
Podiel Bohumíra Šmerala na formovaní Komunistickej strany Československa v prvej dekáde medzivojnovej Československej republiky
}

\author{
MILAN OLEJNÍK \\ Spoločenskovedný ústav v Košiciach, Centrum spoločenských \\ a psychologických vied SAV v Bratislave
}

A role of Bohumír Šmeral in formation of Communist Party of Czechoslovakia in first decade of inter-war Czechoslovak Republic

Abstract: Bohumír Šmeral was one of the most important founders of radical left during the first years of Czechoslovak Republic, even though his political philosophy was never based on total adherence to rigid requirements formulated by the Communist International (CI). As a consequence, he became a target of frequently recurring criticism voiced by leadership of $\mathrm{CI}$ as well as leftist segments in Communist Party of Czechoslovakia (CPC). For his moderate approach in implementation of communist ideology to CPC, he was accused of centrist policy named pejoratively "šmeralism". After death of V. I. Lenin, who tolerated to certain extent Šmeral's independent policy, CI adopted more radical political path - "bolshevization", which was imposition of uncompromising request to rebuild CPC along Russian communist party lines. This led to elimination of Šmeral's political influence in CPC. Šmeral was used by CI to perform external tasks in communist movement. His travels to European countries, even to far-away Mongolia, distanced Šmeral from internal affairs of CPS. He was following instructions given to him by Communist International and during sparse visits to Czechoslovakia was active as a propagator of Soviet Russia, its literature, social order and ideology.

Keywords: Communist Party of Czechoslovakia, Bohumír Šmeral, Comintern, Left.

DOI: https://doi.org/10.24040/ahn.2020.23.02.54-70

Po roku 1989 spracovanie dejín Komunistickej strany Československa (KSČ), vrátane osudov popredných predstavitel'ov strany, nepatrilo medzi preferované témy českej a slovenskej historiografie. Z uvedeného aspektu sú pomerne málo známe politické aktivity čelného predstavitel'a radikálnej l'avice, Bohumíra Šmerala. V dejinách KSČ bol B. Šmeral významnou osobnost'ou komunistického hnutia i ked' nezodpovedal obrazu ortodoxného komunistického vodcu, akými boli Klement Gottwald, Josef Haken, Štefan Major a d'alší, ktorí bez akýchkol'vek pochybností akceptovali rozhodnutia medzinárodného centra komunistického hnutia - Komunistickej internacionály (Kominterny, KI). Do určitej mie- 
Podiel Bohumíra Šmerala na formovaní Komunistickej strany Československa...

ry je prekvapujúce, že Vladimír Iljič Lenin a vedenie Kominterny prejavili ochotu tolerovat' Šmeralovu snahu uprednostňovat' pri hl'adaní stratégie a taktiky Komunistickej strany Československa východiská, ktoré neboli úplne totožné s názormi vedúcich činitel'ov Kominterny. Určujúcim bol predovšetkým jeho vplyv na charakter KSČ, ktorá sa stala predstavitel'kou radikálneho l'avicového hnutia na československej politickej scéne. B. Šmeral nepatril k radikálom v KSČ, roky aktívnej činnosti $v$ sociálnodemokratickej strane na vedúcich postoch $v$ ňom upevnili presvedčenie, že pluralita názorov je nutná aj v komunistickom hnutí. Šmeralov demokratizmus však nenašiel pochopenie medzi predstavitel'mi l'avice v KSČ a stal sa predmetom kritiky aj Komunistickej internacionály v Moskve. Jeho názory si vyslúžili nelichotivé označenie „šmeralizmus“. Napriek kritike doma i v zahraničí, B. Šmeral zostal presvedčeným marxistom a lojálne plnil príkazy Kominterny. V období tzv. bol’ševizácie B. Šmeral stratil politický vplyv v KSČ a pracoval v aparáte Kominterny mimo ČSR.

Už ako študent práv sa angažoval v Československej sociálnodemokratickej strane dělníckej (ČSDSD), konkrétne v redakcii Práva lidu. Pod vplyvom prác Fridricha Engelsa a Karla Marxa dospel k presvedčeniu, že robotníci a rol'níci sú spoločenskou triedou, ktorá má určujúci význam vo vývoji spoločnosti. Šmeralove aktivity sa nevyčerpávali len prekladmi prác klasikov marxizmu. Dokázal získat' uznanie aj ako politik. V roku 1911 bol zvolený do Ríšskej rady - parlamentu so sídlom vo Viedni, v ktorom pôsobil až do konca 1 . svetovej vojny. ${ }^{1}$

Po vypuknutí prvej svetovej vojny dochádzalo na českej politickej scéne k vzostupu nacionalizmu. Výnimkou bol Šmeral, ktorý bol zanieteným stúpencom spojenia Čiech a Rakúska. Významný český publicista Ferdinand Peroutka charakterizoval Šmeralovo politické krédo ako presvedčenie, že Európa dospeje k jednote: „Spojené státy evropské: to byl základ jeho teorie... Patrně mu toto staré jeho vidění spojených evropských států vnitřní přerod ke komunizmu př́mo ulehčovalo: byl to most mezi jeho minulostí a jeho př́tomností, most, který nebylo tréeba spálit na pochodu do Moskvy." ${ }^{2}$ Podl'a historika Jana Galandauera sa nacionalizmus stal ideologickou platformou sociálnej demokracie: „Vznikla v nej síce opozícia, ktorá kritizovala dovtedajšiu politiku, lenže táto kritika nevychádzala z revolučných, ale nacionálno-radikálnych pozícií. “3 Odmietanie nacionalizmu vystavilo Šmerala ostrej kritike v rámci strany. Bol obvinený z kolaborantstva a zrady národných záujmov a stal sa ter-

\footnotetext{
${ }^{1}$ HLUŠIČKOVÁ, Růžena: Bohumír Šmeral, In: KOLÁŘ, František (ed.): Politická elita meziválečného Československa 1918 - 1938. Praha : Pražská edice, k.s., 1998, s. 248.

2 PEROUTKA, Ferdinand: Budování státu 1/2. Praha : Academia, 2003, s. 319.

${ }^{3}$ GALANDAUER, Jan: Bohumír Šmeral. Bratislava : Pravda, 1986, s. 43.
} 


\section{Milan Olejník}

čom nenávistnej kampane. V septembri 1917 sa vzdal funkcií v strane, v poslaneckom klube a v predsedníctve Českého zväzu.

Šmeral, napriek kritike predstavitel'ov sociálnodemokratickej strany, si dokázal uchovat' sympatie značnej časti členov ČSDSD a bol na XII. zjazde strany zvolený do výkonného výboru. I ked' do politického diania v Československu priamo nezasahoval a v roku 1919 pôsobil ako korešpondent periodika Právo lidu vo Švajčiarsku, v strane si udržal vplyv. Krátko po návrate do republiky vo februári 1920 mu vedenie strany ponúklo možnost' cestovat' do Ruska. V tom čase nezastával vyhranené politické stanovisko. Svoj neujasnený postoj charakterizoval v monografii Pravda o sovětovém Rusku: „Otvorene hovorím, že často mávam pochybnosti sám o sebe, či by som v rozhodujúcej chvíli mal dost' statočnosti a či by som nesklamal. Preto idem do Ruska, aby som priamym dotykom s ruskou revolúciou sám seba ešte raz kontroloval, zvýšil pevnost' svojho presvedčenia a posilnil svoju odvahu. ${ }^{\text {" }}$

Galandauer hodnotil Šmeralovu cestu do Moskvy ako obrat v jeho politickej orientácii: „Politicky najvýznamnejším výsledkom Šmeralovej návštevy $v$ Sovietskom Rusku bolo jednak rozhodnutie nevyhýbat'sa d'alej zodpovednosti a postavit' sa na čelo marxistickej l'avice, jednak súhlas vedúcich predstavitel'ov Komunistickej internacionály s jeho metódou budovania revolučnej strany robotníckej triedy v Československu. "5 V zriedkavej zhode s komunistickým historikom Galandauerom opísal Šmeralov pobyt v Moskve Ferdinand Peroutka. ${ }^{6}$

V čase Šmeralovho pobytu v Rusku rozhodujúcim koordinátorom stratégie a taktiky komunistického hnutia na medzinárodnej úrovni bola Komunistická internacionála. K založeniu organizácie došlo 2. marca 1919 na porade predstavitel'ov komunistických strán z 35 krajín, ktorá je v histórii Kominterny definovaná ako jej prvý zjazd. V závere zjazdu Lenin sformuloval primárny ciel' komunistických strán - nastolenie diktatúry proletariátu. ${ }^{7}$

\footnotetext{
4 ŠMERAL, Bohumír: Pravda o sovětovém Rusku. Praha : NPL, 1966, s. 43.

${ }^{5}$ GALANDAUER, J.: Bohumír Šmeral, s. 72.

${ }^{6}$ „Šmeral ... když přišla řeč na taktické otázky ... hájil samostatné, ruským vůdcům nezvyklé stanovisko. Žádal, aby komunistická internacionála učinila pro zvláštní poměry v Československu, kde i dělnictvo je prosyceno nacionalizmem, výjimku a aby dovolila postupovat zde vlastním způsobem. Ačkoliv tento plán silně odporoval radikálním ruským zvyklostem, ačkoli odporoval zejména fanatické Leninově víre o potrebě jasna, argumenty českého návštěvníka byly uznány, bylo mu svěřeno vůdcovství revoluce v jeho zemi a byl na nějakou dobu zproštěn povinnosti výslovně přihlásit ke komunizmu sebe a svou frakci."In: PEROUTKA, F.: Budování státu 1/2, s. 286.

7 „Komunistická internacionála se musela zřetelně a jasně programově oddělit od všech nemarxistických proudů $v$ dělnickém hnutí, t.j. od všech oportunistických směrů a predevším od centrizmu, který byl po válce nadále objektivně nejškodlivějším projevem socialdemokratizmu. "In: VETIŠKA, Rudolf - HRUŠKA, Čeněk - REIMAN, Pavel: Komunistická
} 
Podiel Bohumíra Šmerala na formovaní Komunistickej strany Československa...

Rozkol medzi konzervatívnym krídlom sociálnej demokracie a l'avicou kulminoval po menovaní úradníckej vlády prezidentom Tomášom Masarykom 15. septembra 1920. Šmeral obvinil ministra zahraničia Edvarda Beneša, ministra vnútra Antonína Švehlu a predsedu vlády Vlastimila Tusara zo zosnovania „puču“ a prehlásil, že konflikt medzi vedením sociálnej demokracie a l'avicou je neprekonatel'ný. 16. septembra 1920 obsadili predstavitelia l'avice na čele so Šmeralom sídlo strany Lidový dům. 21. septembra vyšlo prvé číslo l'avicového periodika Rudé právo. ${ }^{8}$

Na celostraníckej úrovni sa protichodné stanoviská konzervatívneho krídla a l'avice prejavili v príprave zjazdu. Z obavy, že l'avica získa väčšinu, zastupitel'stvo strany rozhodlo, „že komunisté na sjezd připuštěni nebudou ... levice 15. záríí, sešla se v Karlíne a usnesla, že sjezd stanovený stranou na 25. zárí, za všech okolností bude se konat." "9

Tlačový orgán l'avice na Slovensku, týždenník Pravda chudoby, informoval, že „Dňa 25. - 28. septembra konal sa v Prahe zjazd soc. d. strany. Na zjazd dostavilo sa zo 440 právoplatne zvolených delegátov 320. Teda tri štvrtiny všetkých delegátov... Už len holý fakt, že na zjazd oproti všetkej agitácii pravice dostavila sa taká obrovská väčšina delegátov, hovorí zato, že robotníctvo u nás, ako aj v Čechách, na Morave a v Sliezsku nie je spokojné s vedením strany a jej doterajšou politikou... V závere delegáti zjazdu prijali tzv. Rezolučné prehlásenie, v ktorom ako výkonný orgán strany ustanovili akčný výbor poverený vedením strany. "10 Najvýznamnejšou osobnost'ou zjazdu bol Šmeral. Peroutka charakterizoval Šmeralov prejav ako zmes radikálnych a umiernených vyjadrení: „(Šmeral) praví: já sem komunista! Hned ho však zase zmírňuje: nechceme provádět puče, neusilujeme o okamžitý převrat, budeme se držet taktiky parlamentní opozice a tř́dní výchovy dělnictva."11 Podl'a Peroutku však v rámci l'avice existovali radikálne skupiny, ktoré so Šmeralovou taktikou nesúhlasili a žiadali, aby strana deklarovala príklon ku komunizmu otvorene a bez odkladu. Tento postoj prevažoval medzi intelektuálmi. ${ }^{12}$

internacionála a čs. dělnické hnutí. Praha : Ústav dějin Komunistické strany Československa, 1959, s. 13.

${ }^{8}$ KLIMEK, Antonín: Velké dějiny zemí koruny Koruny České. Svazek XIII. 1918-1929. Praha : Paseka, 2000, s. 218.

${ }^{9}$ PEROUTKA, Ferdinand: Budování státu 3/4. Praha : Academia, 2003, s. 372.

10 XIII. Právoplatný zjazd českoslov. soc. dem. strany robotníckej. In: Pravda chudoby, 30.

9. 1920 , č. 3.

11 PEROUTKA, F.: Budování státu 3/4, s. 375.

12 „Praktická většina v levici byla spokojená s pomalým Šmeralovým postupem, ale skupina básníků, spisovatelů a ideologů považovala za věc cti a charakteru bez výhrad a bez čekání se prrihlásit k spasitelskému světovému hnutí... Sjezd levice dopadl podle Šmeralova plánu: o vstupu do Třetí internacionály se vůbec nehlasovalo, poněvadž bylo usneseno iluzi sociální demokratičnosti prodlužovat.“In: PEROUTKA, F. : Budování státu 3/4, s. 377 - 378. 
Robotnícke noviny, prezentované ako „Ústredný časopis Československej sociálne demokratickej strany robotníckej na Slovensku“, reagovali na vývoj v strane obvinením Šmerala z dvojakej politiky, zo zavádzania, ktorého výsledkom bol rozkol v sociálnej demokracii ku škode robotníkov v republike. ${ }^{13}$

Obsadenie Lidového domu l'avicou bolo v rozpore s existujúcou legislatívou. Z právneho hl'adiska bola majitel'om Lidového domu a tlačiarne konkrétna osoba - Antonín Němec, ktorý zažaloval radikálov z porušenia zákona. ${ }^{14}$

Dramaticky opísal vyhostenie l'avice z Lidového domu J. Galandauer: „Ked' 9. decembra 1920 silné oddiely polície a četníctva zaútočili na Lidový dům ... bol Bohumír Šmeral práve v redakčných miestnostiach Rudého práva. Okolo dvanástej hodiny bol spolu s ostatnými redaktormi surovo vyvlečený s budovy s roztrhaným odevom a zranený. "15 Dňa 9. decembra predstavitelia l'avice vyhlásili generálny štrajk, ktorý však bez predbežnej prípravy nemal nádej na úspech. Bezpečnostné zložky bez väčších t'ažkosti potlačili štrajk. ${ }^{16}$ Pravda chudoby obvinila pravicové krídlo sociálnej demokracie a vládu zo zrady. ${ }^{17}$ Predstavitelia l'avice vyslali k prezidentovi deputáciu so žiadost’ou, aby vláda, okrem iného, presadila zvýšenie miezd, iniciovala proces socializácie a vyhlásila všeobecnú mobilizáciu. Masaryk prijal len Šmerala, ale ani jeho návrhy neakceptoval. ${ }^{18}$

${ }^{13}$ Robotnícke noviny uviedli, že Šmeral síce v Moskve slúbil radikálnu odluku od sociálnej demokracie, ale uvedomil si, že „vzbudil duchov, ktorých sa sám bojí. Uteká pri tom od prísnej zásady komunistickej a vyhladáva len akúsi zásteru, za ktorú by sa ukryl a dočasne volá do sveta, že je vzdialený od prevratu a komunistických metód“. Šmeral. In: Robotnícke noviny, 3. 10. 1920, č. 199.

14 „25. října pražský okresní soud vyhověl žalobě pro rušení držby... a nařídil akčnímu výboru levice, aby vyklidil obsazený dům, tiskárnu i redakci... Dr. Šmeral správně vystihl poměry, řeklli: „Ve vědomí všech př́slušníku strany bylo jako něco úplně samozrejejého, že toto osobní vlastnictví je vlastnictvím pouze fiktivním." In: PEROUTKA, F.: Budování státu 3/4, s. 453, 454. ${ }^{15}$ GALANDAUER, J.: Bohumír Šmeral, $s .76$.

16 „Státní orgány, policie, četnictvo a armáda, zahájili tak rozsáhlou a dobře organizovanou potlačovací akci, jakou republika ještě nepoznala. Podobala se všeobecné protistávkové mobilizaci. Měla vedení stávky v průmyslových centrech i v místech doslova rozdrtit. Šmeral a jeho lidé zatčeni nebyli, tisk levice byl však hned cenzurován a zastavován, veřejná shromáždění systematicky zakazována, v krajových centrech strany byli provádeny prohlídky a zabavovány tiskoviny, nad některými územími byl vyhlášen výjimečný stav nebo dokonce stanné právo." In: KÁRNíK, Zdeněk: České země v ére První republiky (1918 - 1938). Díl první. Vznik, budování a zlatá léta republiky (1918 - 1929). Praha : Libri, 2000, s. 144.

17 „To všetko dosvedčuje a potvrdzuje len to, že vláda a s ňou spriahnutí zradcovia socializmu, pravičiari, hl'adali príčinu, ako by mohli pomocou ozbrojenej polície a žandarmerie udriet' na robotnícky dom a zabrat' ho pre seba. "Hrozné násilie na robotnom l'ude. In: Pravda chudoby, 18. 12. 1920, č. 14.

18 „Ještě za generální stávky, 14. prosince, poskytl Masaryk audienci Šmeralovi... Rozhodně odmítl „,kompromisní" návrhy Šmerala..., že totiž levice odvolá již zvolna se hroutící stávku, pokud budou legalizovány zábory, levičáky obsazených podniků a statků, udělena amnestie 
Podiel Bohumíra Šmerala na formovaní Komunistickej strany Československa...

Bez šance na vít’azstvo bol štrajk ukončený, pričom l'avica nedosiahla žiadny úspech. ${ }^{19} \mathrm{~S}$ neochvejným optimizmom hodnotila, i napriek kolapsu, generálny štrajk Komunistická internacionála: „Českým dělníkům pravíme: Odvahu soudruzi! Rusko po červenci mělo ř́jen! U vás tomu bude stejně. At’ žije proletářská revoluce v Československu a na celém světě!'20

Šmeral a d'alší členovia poslaneckej snemovne $\mathrm{z}$ radov l'avice využili svoje mandáty a vystúpili s kritikou postupu vlády. Argumentovali, že obsadenie Lidového domu bolo aktom policajného násilia, pretože: „Všechno právo rozhodovati o něm měla a má podle všeobecných zásad demokracie i podle organizačního řádu strany většina této strany, konkrétně řečeno výkonný výbor většinou organizovaných členů zvolený a o jejich důvěru se opírající."21

K rozkolu spela situácia aj v rámci sociálnodemokratickej strany na Slovensku. Na konferencii v Martine, ktorá sa konala napriek zrušeniu bratislavským výkonným výborom, predstavitelia radikálneho krídla založili 19. septembra 1920 akčný výbor marxistickej l'avice. Zvolat' zjazd, na ktorom by sa skonštituovali základy radikálne l'avicovej strany, sa rozhodli účastníci počas porady v Nitre 20. novembra 1920.

V zjazdových rokovaniach konaných 16. - 17. januára 1921 v L’ubochni zohrali významnú úlohu príslušníci mad'arskej minority, ktorí disponovali hlbšou znalost'ou marxistickej teórie. Zjazd mal multietnický charakter. Z celkového počtu 149 delegátov sa rokovaní zúčastnilo 88 Slovákov, 36 Mad'arov, 15 Nemcov, 6 Ukrajincov a 4 príslušníci židovskej národnosti. Napriek pestrému národnostnému zloženiu počas kongresu sa nevyskytli podstatné rozdiely. S výnimkou premenovania strany na komunistickú, o ktorom predbežne nebolo rozhodnuté, zvyšných 20 podmienok postulovaných Komunistickou internacionálou bolo akceptovaných. ${ }^{22}$

Sl’ubný začiatok rokovania, počas ktorého 16. januára predstavitelia l'avice ${ }^{23}$ v nadšených príhovoroch črtali skvelú budúcnost' komunizmu na Slovensku, narušil zásah úradov. Avšak skôr, ako mohla brachiálna

za činy během stávky a nepokojů, nastoupí nová vláda, která se zaváže provést socializaci, a dojde $k$ zvýšení dělnických platů. Masaryk drsně dodal, že ti bolševici, kteř́ nechtějí svobodu, jaká je v ČSR, se mohou vystěhovat. "In: KLIMEK, A.: Velké dějiny..., s. 225.

19 „Už 12. prosince odvolali generální stávku v Praze. Od té chvíle skládali naděje už jen v Kladno a v Brno. Nyní však vystoupil - poprvé - zcela energicky dr. Šmeral. Odjel na Kladno a v osobním jednání zlomil odpor tamních radikálu․ 16. prosince, když už z ní jen tu a tam doutnali zbytky, byla stávka i formálně po celé republice odvolána. "In: PEROUTKA, F.: Budování státu 3/4, s. 463. ${ }^{20}$ PEROUTKA, F.: Budování státu 3/4, s. 464.

${ }^{21}$ Poslanecká sněmovna N. S. R. Č. 1920. I. volební období. 2. zasedání 1056. Naléhavá interpelace poslanců Tesky, Skaláka, dra Šmerala, Kreibicha a soudruhu na celú vládu. V Praze 14. prosince 1920.

22 ZINNER, Paul E.: Communist Strategy and Tactics in Slovakia, 1918 - 1948. New York London : Frederik A. Praeger Publisher, 1963, s. 33

${ }^{23}$ Medzi inými Marek Čulen, Herman Tausig, Július Verčík. 
moc zasiahnut', delegáti schválili podmienky stanovené pre vstup do Kominterny. Predstavitelia l'avice charakterizovali zásah štátnych úradov ako protiprávny a protestovali v senáte. ${ }^{24}$

Významným krokom k sformovaniu komunistickej strany bol zjazd marxistickej l'avice konaný v dňoch 14. - 16. mája 1921 v Prahe. Na zjazde sa zjednotili všetky národnostné sekcie (česká, slovenská, mad’arská a reprezentanti ukrajinskej l'avice) s výnimkou nemeckej a pol'skej, ktoré ostali organizačne samostatné. Pre príklon československej l'avice ku Komunistickej internacionále mala určujúci význam zmena Šmeralovho postoja v otázke pripojenia ku Komunistickej internacionále a akceptovania jej 21 podmienok. Vstup l'avice do Komunistickej internacionály bol schválený rozhodujúcou väčšinou delegátov. ${ }^{25} \mathrm{~V}$ závere zjazdu delegáti reprezentujúci národnostné sekcie prijali rezolúciu, v ktorej okrem iného deklarovali: „Stojíme na stanovisku III. Internacionály a prijímame 21 podmienok, ako sme to už boli urobili na rozohnanom zjazde žandárskou brutalitou v L'ubochni."26 Nadšenú atmosféru na zjazde charakterizoval v závere svojho prejavu Šmeral, ktorý so zanietením náboženského fanatika uistil delegátov, že: „Jsme víc než politická strana. Jsme prededvoj nového života. Tvoříce nové poměry, chceme tvořiti také nové lidi. “27

Rozhodnutie zjazdu vyvolalo priaznivú odozvu Komunistickej internacionály. Výkonný výbor organizácie v odpovedi na zjazdovú rezolúciu uviedol: „Sme presvedčení, že vaša strana so svojimi stotisíc príslušníkmi je schopná zaujat' vedúce miesto v komunistickej Internacionále... Očakávame, že vaša strana na III. svetový kongres Komunistickej Internacionály vyšle čo možno najviac delegátov! Nech žije silná komunistická strana Československa! G. Zinoviev."28

\footnotetext{
${ }^{24} \mathrm{~V}$ interpelácii reprezentantov l’avice je uvedené: „Dňa 16. januára 1921 konal sa v Lubochni na Slovensku, v župe liptovskej zjazd komunistov zo Slovenska ... V odpoludňajšom zasadnutí, celkom bez odôvodnenia a bez každej príčiny prehlásil zjazd za rozpustený a nechal účastníkov čatou četníkov brachiálnou mocou rozohnat'." V závere interpelácie predstavitelia l'avice v senáte žiadali, aby minister vnútra „zdôraznil najmä úradom na Slovensku, aby podobným zneužívaním úradnej moci nepodkopávala sa autorita štátu..." Senát Národního shromáždění R. Č. r. 1921 1. volební obd. 2. zasedání. Tisk 417. Interpelácia senátora F. Zimáka a súdruhov na ministra vnútra v záležitosti rozpustenia zjazdu komunistov zo Slovenska v L’ubochni.

${ }^{25}$ Pravda chudoby nadšene informovala o priebehu vol'by: „15. máj 1921 je jedným z najslávnejších dní proletariátu československého. Vyslanci robotníctva, zhromaždení na zjazde soc. dem. strany l'avej v Karlíne v počte 562, na otázku predsedu či pristupujú na 21 podmienok III. internacionály, povstávajú zo svojich miest a s rozhodnou jednomysel'nost'ou dvíhajú ruky a volajú: Áno!"V mene l'udu. In: Pravda chudoby, 22. 5. 1921, č. 29.

${ }^{26}$ V mene l'udu. In: Pravda chudoby, 22. 5. 1921, č. 29.

27 Protokoly sjezdů KSČ. I. svazek. Praha 1958, s. 114, 153; ČIHÁK, Miroslav: Prosazení leninského pojetí masovosti KSČ v letech 1921 - 1938. Praha : Státní pedagogické nakladatelství, 1978, s. 92.

${ }^{28}$ Výkonný výbor III. komunistickej Internacionály komunistickej strane Československa. In: Pravda chudoby, 5. 6. 1921, č. 23.
} 
Podiel Bohumíra Šmerala na formovaní Komunistickej strany Československa...

Vol'bu radikálnej l'avice nenechala sociálna demokracia bez povšimnutia. Robotnícke noviny charakterizovali dianie na zjazde ako porážku umiernenej Šmeralovej línie a vít’azstvo radikálneho programu predsedu nemeckej sekcie Kreibicha. Redakcia vyjadrila presvedčenie, že delegáti zjazdu tým, že akceptovali podmienky postulované Kominternou, dobrovol'ne prijali „duševné otroctvo"vo vzt’ahu k organizácii. ${ }^{29}$

Šmeralova koncepcia masovej strany nemala podporu l'avice. ${ }^{30}$ Šmeral odmietol kritiku radikálov s poukazom na prevažujúci vplyv socialistických strán na robotnícku triedu, na ich masovú základňu a dobrú organizáciu, nad ktorými je možné zvít’azit' len za predpokladu, že komunisti dokážu získat' masy robotníkov na svoju stranu. ${ }^{31}$

Stal sa terčom kritiky radikálneho krídla tiež na III. kongrese Kominterny v Moskve, počas ktorého bola pertraktovaná aj žiadost' KSČ o prijatie do organizácie. ${ }^{32}$ Okrem Bohumila Jílka, Václava Bolena a d’alších predstavitel'och českej radikálnej l'avice pranieroval celkovú koncepciu Šmeralovej stratégie tiež K. Kreibich. Jeho argumenty však vedenie Kominterny odmietlo. Primárnym kritikom jeho názorov bol V. I. Lenin. ${ }^{33}$ Autoritu vodcu ruskej revolúcie nebolo možné ignorovat' a Leninovo presvedčenie o správnosti budovania masovej KSČ Kreibich akceptoval. ${ }^{34}$

\footnotetext{
${ }^{29}$ „VŠetko úsilie Šmeralovo - aby situáciu zachránil tým, že zjazd by rozhodol síce pre podmienky a zmenu (mena) ... ale súčasne vynútil si, aby československá komunistická strana mohla svoju taktiku určovat'si sama - padlo. Zvít'azilo brnenské krajne komunistické krídlo a zvít’azil hlavne Šmeralov úhlavný odporca Kreibich... Českí a slovenskí delegáti sami $z$ nevedomosti o tom rozhodli. Že behom času t’ažko následky toho ponesú, o tom niet sporu... Keby delegáti zjazdoví len trochu boli uvažovali, poznali by svoje duševné otroctvo, ktoré dobrovolne prijali okamžite po odhlasovaní prístupu ku komunistickej Internacionále." Po zjazde komunistickej strany. In: Robotnícke noviny, 19. 5. 1921, č. 108.

30 „Tzv. ultral'avá skupina, ktorej hlavnými predstavitel'mi boli B. Jílek a V. Houser, postavila proti Šmeralovej koncepcii masovej strany predstavu ,malej strany - jadra', ktorá by bola vybudovaná ako vojensko-politická organizácia a sústred'ovala by len nevel'ké množstvo ,čistých' komunistov. Šmeralovo úsilie o dosiahnutie prechodu čo najväčšieho počtu sociálnodemokratických robotníkov do komunistickej strany označovali za centrizmus." In: GALANDAUER, J.: Bohumír Šmeral, s. 80.

${ }^{31}$ GALANDAUER, J.: Bohumír Šmeral, s. 80.

32 „Československá delegácia musela na kongrese čelit’ ostrým výčitkám predsedu nemeckého oddelenia KSČ K. Kreibicha. Terčom kritiky bol predovšetkým B. Šmeral. Vyčítal mu oportunistické prvky v referáte, ktorý Šmeral predniesol na ustanovujúcom zjazde, vel'kú opatrnost', malú bojovnost' a pod. Kritika ... vychádzala z nesprávnej ,ofenzívnej teórie', ktorá nebrala do úvahy, že kapitalizmus sa čiastočne upevnil a žiadala, aby komunistické strany rozvinuli útok proti buržoázii." In: GALANDAUER, J.: Bohumír Šmeral, s. 85.

33 „V. I. Lenin dal za pravdu Bohumíru Šmeralovi a většině vedení KSČ, jež usilovalo o vytvoření masové strany a další rozšírení a upevnění vlivu KSČ v masách." In: BRADÁČ, Zdeněk: Boj za bolševizaci KSČ v období dočasné stabilizace kapitalizmu I. 1924 - 1925. Praha : Státní nakladatelství politické literatúry, 1954, s. 43.

34 „B. Šmeral i K. Kreibich ve svých vzpomínkách shodně uvádějí, že ... setkání a diskuse s V. I. Leninem jim pomohly překlenout rozdíly v názorech a pochopit všechny souvislosti komunis-
} 
Lenin však nesúhlasil bezvýhradne ani s názormi B. Šmerala. Výsledkom kompromisu a súhlasu oboch predstavitel'ov KSČ s požiadavkami Kominterny bolo prijatie Komunistickej strany Československa do III. internacionály. ${ }^{35}$ Pravda chudoby informovala o výsledku III. kongresu Kominterny, ktorý odmietol tzv. ofenzívnu teóriu radikálnej časti l’avice a vytýčil ako prvoradú úlohu strany vybudovat' masovú základňu. ${ }^{36}$

Lenin zásadne nesúhlasil s rozdelením KSČ na dve samostatné sekcie. Vyzval Šmerala a Kreibicha, aby stranu zjednotili. Na základe rozhodnutia Exekutívy Komunistickej internacionály (EKI) bol termín konania zlučovacieho zjazdu KSČ stanovený na 30. októbra - 2. novembra 1921.

Vo vystúpení na zjazde Kominterny Šmeral deklaroval svoje hlboké presvedčenie o superiorite a nevyhnutnom vítazstve komunizmu. Delegáti zjazdu z ČSR však boli šokovaní biedou, aká panovala v sovietskom Rusku. Pravda chudoby bola nútená priznat' zúfalú situáciu a vo viacerých článkoch apelovala na robotníkov, aby v rámci svojich možností pomohli hladujúcim obyvatel'om Ruska. Ako príčina katastrofálnej situácie nebola uvedená neschopnost' sovietskeho vedenia, ale sucho. Ked'že podl'a názoru redakcie hladomor ohrozoval bezpečnost' sovietskeho štátu a tento stav mohli zneužit' kapitalistické štáty na útok proti Rusku, bolo internacionálnou povinnost'ou proletárov celého sveta v rámci svojich možností pomôct' krajine Sovietov. ${ }^{37}$

Plniac požiadavku Komunistickej internacionály sa 30. októbra 1921 v Prahe zišli všetky sekcie KSČ. Po prednesení referátov B. Šmerala a K. Kreibicha delegáti schválili zlúčenie všetkých sekcií do jednotnej strany. V rezolúcii „Zlučovacieho zjazdu KSČ“ prijatého účastníkmi sa

tické politiky. “In: ČADA, Václav: Vznik KSČ jako revoluční strany nového typu. Praha : Svoboda, 1968, s. 114.

35 „Po intenzívních jednáních, ve kterých byly překonány v podstatě všechny dosud existující rozdíly $v$ pohledu na základní otázky, budování i politiku revoluční strany nového typu v Československu, rozhodl III. kongres Komunistické internacionály príijmout obě části do Komunistické internacionály. "In: ČADA, V.: Vznik KSČ..., s. 114.

36 „Kongres III. komunistickej internacionály, z ktorého sa už naša delegácia vrátila, vyznel: Ani útok, ani obrana, ale získanie más... Dôvody... sú korene v terajšom svetovom položení. Kapitalistickej buržoázii za pomoci sociál-zradcov sa podarilo zorganizovat' žandarmeriu, políciu a vojsko pre svoju obranu proti proletariátu. Proletariát nemôže proti organizovanej moci buržoázie vystupovat' v malých stranách, ako to bolo možné v rokoch 1917-19, ked' triedny aparát buržoázie, vojsko, žandarmeria, polícia bol v rozklade a dezorganizácia vnútri štátu... Preto Lenin na kongrese III. Internacionály vel'mi ostro vystúpil proti smeru, ktorý chcel bez náležitých príprav a za každú cenu útočit'. Najsamprv vel'ké strany a potom rozhodný boj s buržoáziou. Taktika našej československej komunistickej strany, ohl'adom utvorenia vel'kej strany našla takto odobrenie na kongrese. "Ako zvít'azíme. In: Pravda chudoby, 7. 8. 1921, č. 51. 37 Napríklad: Pomoc sovietskemu Rusku. In: Pravda chudoby, 7. 8. 1921, č. 51; Robotníkom a robotníčkam v Československej republike. In: Pravda chudoby, 11. 8. 1921, č. 53; Čo robí sovietska vláda pre hladujúci l'ud a čo je povinnost'ou proletariátu celého sveta. In: Pravda chudoby, 8. 9. 1921, č. 59. 
Podiel Bohumíra Šmerala na formovaní Komunistickej strany Československa...

uvádza: „Zástupci proletariátu českého, slovenského, německého, polského, mad'arského a ukrajinského, shromáždění na společném Slučovacím sjezdu, zdraví usnesení Třetího světového kongresu Komunistické internacionály, který vyslovil požadavek, aby byla vytvořená jednotná mezinárodní komunistická strana Československa. Jsou odhodláni provést sjednocení s nadšením tím větším, ježto požadavek Třetího světového kongresu je v úplném souhlase $s$ vůli proletariátu všech národů tohoto státu vytvořiti mezinárodní proletářskou jednotnou frontu, jak se to každým dnem ostřeji projevovala."38

V snahe zachovat' zdanie nezávislosti na Kominterne, Šmeral v prejave zdôraznil, že „nepodřídili jsme se moskevskému usnesení pouze $z$ důvodů disciplíny, nýbrž že také na naše přesvědčení působily důvody, ze kterých tam usnesení vzešlo. "39 V d'alšej časti prejavu Šmeral citoval predsedu Kominterny Grigorija Zinovieva, podl'a ktorého bolo medzinárodné revolučné hnutie v útlme, avšak tento stav bol dočasný a revolúcia s novou silou nastolí na celom svete vládu robotníckej triedy. Šmeral, vychádzajúc z optimistickej predpovede Zinovieva, prehlásil: „V této situaci musíme míti stranu umožňující rychlé taktické přizpůsobování se rychle měnícím se situacím... Tomuto stavu odpovídá u nás opravdu jednotná centrálně řízená mezinárodní strana komunistická."40 Týmito slovami však poprel svoje predošlé prehlásenia, že určitá miera tolerancie názorových rozdielov je nutným prostriedkom dosiahnutia správnej stratégie v reakcii strany na meniacu sa politickú situáciu.

Zlučovací kongres sa zároveň stal medzníkom definitívneho zmierenia B. Šmerala a K. Kreibicha. Predstavitelia oboch národnostných sekcií akceptovali požiadavku Kominterny, aby zmenili svoje protichodné stanoviská a uzavreli kompromis. ${ }^{41}$

Odmietnutie radikálnej línie v komunistickom hnutí vyústilo do sformovania koncepcie tzv. jednotného frontu. I ked' komunistické strany viacerých krajín kritizovali koncept jednotného frontu ako odklon od revolučnej stratégie, stanovisko Komunistickej internacionály bolo

\footnotetext{
38 Protokol Zlučovacího sjezdu komunistických stran Československa, konaného v PrazeSmíchově ve dnech 30. ř́jna - 4. listopadu 1921, Praha 1922, s. 44 - 45. In: Dokumenty moderní doby. Praha : Svoboda, 1978, s. 158 - 159.

${ }^{39}$ KLÍR, Miroslav: Studijní materiály k dějinám Komunistické strany Československa v letech 1921 - 1924, Řeč poslance soudruha Bohumíra Šmerala. Praha : Státní nakladatelství politické literatury, 1959, s. 70.

${ }^{40}$ KLÍR, M.: Studijní materiály..., s. 71.

41 „V době mezi III. kongresem KI a slučovacím sjezdem KSČ (31. ř́jna až 4. listopadu 1921) se prekonaly rozpory mezi stanovisky Karla Kreibicha a Bohumila Šmerala. Šmeral uznal nesprávnost svého odporu proti okamžitému sloučení, Kreibich se přesvědčil o pochybenosti ,teorie ofensivy! Tak se na základě líni III. kongresu vytvořil ve vedení KSČ nový sjednocený blok Šmeral, Kreibich, Zápotocký."In: HÁJEK, Miloš: Jednotná fronta. K politické orientaci Komunistické internacionály v letech 1921 - 1935. Praha : Academia, 1969, s. 30 - 31.
} 
rozhodujúce. ${ }^{42} \mathrm{~V}$ existujúcej medzinárodnej politickej situácii mal byt' jednotný front nemennou stratégiou komunistických strán $\mathrm{v}$ procese získania robotníckej triedy. ${ }^{43}$ Koncepciu jednotného frontu striktne odmietlo radikálne krídlo v KSČ reprezentované Bohumilom Jílkom, Václavom Bolenom a Václavom Šturcom. V mocenskom zápase však Jílkova skupina prehrala a rozhodujúceho vplyvu sa zmocnili stúpenci III. Internacionály, ktorí získali väčšinu v ústrednom výbore KSČ. Dôsledkom straty väčšiny v ústrednom výbore bolo vylúčenie Jílkovho krídla z Komunistickej strany Československa. ${ }^{44}$ Pravda chudoby priznala, že z KSČ bola vylúčená Jílková skupina, avšak komentovala udalost' ako akt nevyhnutný pre udržanie disciplíny v strane. ${ }^{45} \mathrm{~V}$ diametrálne odlišnom tóne informovali o konflikte v KSČ Robotnícke noviny. ${ }^{46}$ Periodikum vyjadrilo názor, že porušenie disciplíny zo strany opozície nebolo skutočnou príčinou, ale Šmeralova obava z rozštiepenia KSČ. 47

42 „Taktický prístup komunistických strán v tejto vývojovej etape stanovil III. kongres Komunistickej internacionály: komunistické strany mali bojovat’ za čiastkové konkrétne požiadavky pracujúcich más a získat' vplyv na väčšinu príslušníkov robotníckej triedy. Zasadanie Exekutívy Komunistickej internacionály v decembri 1921 prijalo tézy, ktoré ukladali komunistickým stranám, aby vyvinuli iniciatívu pri budovali jednotného frontu celej robotníckej triedy v boji proti ofenzíve kapitálu. "In: GALANDAUER, J.: Bohumír Šmeral, s. 91.

43 „Exekutiva již v prosinci 1921 upozornila, že jde o nový, závažný a stály nástroj boje o masy, který bude možné odložit teprve tehdy, až bude získaná nejen většina dělnické tř́ldy, ale i politická moc." In: MENCL, Vojtěch: Na cestě k jednotě KSČ v letech 1921 - 1923. Praha : Rudé právo, 1964, s. 38.

${ }^{44}$ „Bolen rezignoval na členství v užším výkonném výboru (UVV). Jílek se vzdal funkce generálního organizačního tajemníka. Na Šmeralův návrh byl do UVV zvolen Zápotocký a pověřen funkci generálního tajemníka... Stoupenci linie III. kongresu tak získali v UVV většinu." Konflikt medzi oboma skupinami však pokračoval: „Politika jednotné fronty narazila na ostrý odpor Jílkovy skupiny. Boj mezi ní a Šmeralovým vedením se vyhrotil; výkonný výbor vyloučil Jílkovce ze strany. "In: HÁJEK, M.: Jednotná fronta..., s. 40.

45 „23. a 24. sept. konala sa v Prahe ríšska konferencia komunistickej strany Československa... Konečne musela sa konferencia zaoberat' jednou t'ažkou a bolestnou otázkou ... niekol'ko členov strany, ba priam výkonného výboru porušilo t'ažko disciplínu... Strana komunistická nemohla takéto jednanie trpiet'. Preto musela zakročit' tvrdo a bezohl'adne voči osobám, ktoré sa tohto činu dopustili...Konferencia uzniesla sa, aby doterajší súdruhovia: Bolen, Šturc, Jílek, Udržalová a Stabihoud boli zo strany vylúčení. "Ríšska konferencia komunistickej strany Československa. In: Pravda chudoby, 29. 9. 1929, č. 79. (Pojem ríšsky sa v dobovej tlači používal vo význame „celoštátny“.)

${ }^{46}$ Podl'a Robotníckych novín k rozvratu v KSČ došlo v dôsledku boja „medzi vodcami komunistickej strany, z ktorých jedni pod vedením starého Václava Šturca chceli mat'stranu komunistickú, zatial' čo druhí, stojaci v otrockých službách politického podvodníka Šmerala usilovala i o vylúčenie posledných komunistických zbytkov v komunistickej strane... Teraz táto celá komunistická opozícia bola vylúčená z komunistickej strany." Rozvrat komunistickej strany. In: Robotnícke noviny, 28. 9.1922, č. 216.

47 „Ak bolo siahnuté k ich vylúčeniu, iste k tomu boli vážne príčiny a nemohlo tomu byt'len pre púhe porušenie straníckej disciplíny, ako by komunisti radi svetu nahovorili. Fakt je ten, že komunistické strana začína sa rozkladat' a strach pred rozkladom a úplným rozvratom to 
Podiel Bohumíra Šmerala na formovaní Komunistickej strany Československa...

Rozhodnutie výkonného výboru KSČ však neznamenalo definitívny koniec členstva radikálov v strane. Predstavitelia Komunistickej internacionály, znepokojení vývojom situácie v KSČ, zasiahli s ciel'om vnútit' obom znepriateleným frakciám kompromis. Príležitost’ou pre ingerenciu sa stal IV. kongres Komunistickej internacionály. Vedenie organizácie kreovalo špeciálnu československú komisiu poverenú vyšetrit’ okolnosti, ktoré viedli k boju o moc medzi oboma skupinami a k vylúčeniu radikálneho krídla z KSČ. Komisia dospela k záveru, že obvinenia vznesené l'avicou boli neopodstatnené a boli hrubým porušením straníckej disciplíny. Eliminácia l'avice však mohla viest' k rozštiepeniu KSČ už beztak oslabenej poklesom členstva. Komisia preto inštruovala vedenie strany, aby zrušilo vylúčenie a usilovalo o vyriešenie krízy na základe kompromisu. ${ }^{48}$ Kongres Kominterny síce upustil od vylúčenia Jílka, Bolena a d'alších členov radikálnej frakcie z KSČ, ale ich zotrvanie v strane podmienil dodržiavaním bezpodmienečnej disciplíny. ${ }^{49}$ Šmeralove vít’azstvo bolo logickým dôsledkom odmietnutia l'avicovej frazeológie, ak mala mat' stratégia jednotného frontu nádej na úspech.

Úplnú subordináciu Komunistickej internacionále potvrdili predstavitelia KSČ počas tzv. I. riadneho kongresu strany, konaného v Prahe 2. - 5. februára 1923. Bez výhrad boli schválené uznesenia IV. kongresu odsudzujúce útok l'avice na vedenie KSČ a politika jednotného frontu. ${ }^{50}$ V správe z rokovania IV. kongresu Kominterny Šmeral obvinil predstavitel'ov l'avice $\mathrm{z}$ neobjektívnej kritiky straníckeho vedenia a z útoku na

bol, ktorý Šmerala , ako vodcu a diktátora strany, prinútil k tomuto kroku. " Komunistická strana v rozvrate. In: Robotnícke noviny, 1. 10. 1922, č. 219.

48 „IV. kongres KI rozhodně odsoudil jednání ,ultralevé opozice v KSČ jako nejhrubší narušení stranické disciplíny... Na kongresu byl odhalen protistranicky charakter ,platformy' opozice. Kongres ji v resoluci o československé otázce charakterizoval jako anarchosyndikalistickou úchylu, jež je v rozporu se základními zásadami Komunistické internacionály. Současně však IV. Kongres zrušil usnesení celostátní konference KSČ o vyloučení vedoucí skupiny ,ultralevé opozice, poněvadž ... protistranická činnost a protikomunistické názory nebyly dostatečně odhaleny před celou stranou a hrozilo nebezpečí vytvoření ,levé KSČ (podobně, jako tomu bylo v Německu a Rakousku). Kongres zaměnil vyloučení př́snou důtkou, zbavil viníky všech stranických funkcí až do př́ítího sjezdu KSČ a zdůraznil, že opozice je povinná plně se podř́idit jednotné stranické disciplíně, všem usnesením a směrnicím stranických orgánů.“In: MENCL, V.: Na cestě k jednotě..., s. 67.

${ }^{49}$ „IV. Kongres ... .zdôrazňuje nutnost' najprísnejšieho dodržiavania záväzkov, ktoré opozícia prijala, totiž podrobit' sa bezpodmienečne disciplíne strany." Rezolúcia IV. kongresu III. internacionály o otázke komunistickej strany v Československej republike. In: Pravda chudoby, 22.12.1922, s. $103-104$.

50 „Sjezd jednomyslně schválil usnesení IV. Kongresu KI o československé otázce, které pomohlo KSČ úspěšně odrazit útok, ultralevých živlư', překonati vnitrostranickou krisi a věnovati se snovou silou práci a boji... V usnesení sjezdu ,Stanovisko strany o jednotné frontě a dělnické vlády' se v duchu usnesení IV. Kongresu Komunistické internacionály zdůrazňuje jako hlavní úkol KSČ boj za vytvoření jednotné fronty dělnické třídy. "In: MENCL, V.: Na cestě k jednotě..., s. 73. 
jeho osobu. Šmeral charakterizoval taktiku l'avice ako cestu k deštrukcii robotníckej triedy. ${ }^{51}$

Pre Šmerala a jeho stúpencov sa v nasledujúcom období primárnou opozíciou stala l'avica. Deliaca čiara medzi oboma uvedenými ideologickými prúdmi bola výrazne definovaná národnostne i generačne. ${ }^{52}$

S kritikou vedenia KSČ vystúpili predstavitelia l'avice počas zasadnutia V. kongresu Komunistickej internacionály konaného 17. júna - 8. júla 1924 v Moskve. L’avica zastúpená v československej delegácii tvorila menšinu, ale jej význam umocňovala skutočnost', že voči situácii $\mathrm{v}$ KSČ malo námietky aj vedenie Komunistickej internacionály. ${ }^{53} \mathrm{~V}$ záverečnej časti politickej správy kongresu Kominterna obvinila KSČ z nedostatku „revolučného vedenia“, deklarovala nutnost' odstránit' „revizionistické živly" a kooptovat' do výkonného výboru "zástupcov z radov robotníkov".54 Šmeral bol častým terčom kritiky tak l'avice v KSČ, ako aj Komunistickej internacionály. Konfliktu s vedením Kominterny sa však snažil vyhnút' za každú cenu. ${ }^{55}$

Konflikt v KSČ sa stal pre Robotnícke noviny príležitost'ou poukázat' na chybu, ktorej sa dopustil Šmeral, ked' inicioval rozkol sociálnodemokratickej strany. Podl'a redakcie sa v komunistickej strane dostali do popredia radikáli rozhodnutí ovládnut' stranu a zbavit' Šmerala akého-

51 „Čo vlastne zo všeobecnejšieho hl'adiska predstavovala opozícia? Surovú beztvárnu nespokojnost' más...Vít'azstvo tejto surovej nespokojnosti by fakticky atomizovalo triedny boj, viedlo by k rozkladu robotníckej triedy, k porážke proletariátu..." In: GALANDAUER, J.: Bohumír Šmeral, s. 102.

52 „Od založení KSČ se dělicí čára politických různic často shodovala s dělicí čárou různic národnostních. Pravicové úchylky se později rozvíjely spíše v českých zemích, zatímco ,levičáctví a určité nohsledství Kominterny se vyskytovalo více u komunistů národnostních menšin." In: RUPNIK, Jacques: Dějiny Komunistické strany Československa. Od počátku po prevzetí moci. Praha : Academia, 2002, s. 56.

53 „V súvislosti s odhalením pravicového nebezpečenstva v medzinárodnom robotníckom hnutí poukázalo sa na V. kongrese Kominterny aj na prejavy pravicových tendencií v KSČ. Vedenie KSČ bolo kritizované, že proti týmto pravicovým tendenciám nedostatočne bojovalo." In: PLEVA, Ján: Príspevok k dejinám bol'ševizácie KSČ na Slovensku a na Zakarpatsku. Bratislava : Vydavatel'stvo politickej literatúry, 1962, s. 35.

54 PLEVA, J.: Príspevok k dejinám..., s. 36.

55 Podla komunistického historika J. Křena: „Podobně jako v celé straně, byla složitá a komplikovaná situace i ve vedení strany, které ani zdaleka nebylo jednolitým celkem. Vedle pravice a levice, které stály proti sobě v nejostřejším boji, byla ve straně i Ústředním výboru skupina středu; v Ústředním výboru byla představována hlavně starými autoritativními vůdci v čele se soudruhem Šmeralem, kteří těžce překonávali určité sociálně demokratické tradice, a proto $v$ tomto vnitrostranickém boji kolísali... Levicová většina UV nedovedla $k$ této skupině najít správný poměr, neměla dosti trpělivosti k tomu, aby získala tyto soudruhy na svou stranu. Levicoví členové vedeni strany mnohdy - a vtom nutno spatrovat jisté sektár̆ské rysy jejich postupu - nesprávně směšovali tuto skupinu s pravičáckými živly. "In: KŘEN, J.: Československo v období dočasné a relativní stabilizace kapitalizmu (1924 - 1929). Praha: Státní nakladatelství politické literatury, 1957, s. 88 - 89. 
Podiel Bohumíra Šmerala na formovaní Komunistickej strany Československa...

kol'vek vplyvu. ${ }^{56}$ Šmeral reagoval na kritiku v prejave prednesenom počas krajskej konferencie v Kladne 28. septembra 1924. Stotožnil sa s názorom, že „usnesení světového sjezdu, když jsou jedenkráte učiněna, jsou pro každého soudruha, pro každou stranu závaznými. Každý je musí přijmout, každý je musí provádět. To znamená, že my přijímáme a budeme provádět všechna usnesení, jež odhlasoval V. sjezd... Ale naproti tomu... nikdo nesmí býti označován za ,horšího komunistu', za ,oportunistu', jestli v té době, kdy se o rozhodnutí sjezdu připravovalo, hájil v debatě $v$ mezích komunistické zásadovosti stanovisko odlišné, než pro jaké nakonec většina sjezdu rozhodla... I v našem hnutí musí býti priznána jistá volnost různým názorů."57 Šmeralove argumenty vedenie Kominterny neuspokojili. V reakcii na Šmeralov referát, reprezentant organizácie Dmitrij Manuilskij napísal: „Šmeral nedal přímou odpověd' ani na jednu z kardinálních otázek českého politického života a českého revolučního dělnického hnutí... Řekněme přátelsky otevřeně, že to nebyla řeč politického vůdce, nýbrž nadaného, rozumného diplomata, jenž vybudoval svoji dialektiku na formálně logických závěrech s přimísením náhledů sentimentálně lyrického druhu. "58

Napätú atmosféru v KSČ charakterizovali rokovania II. zjazdu v dňoch 31. októbra - 4. novembra 1924. Rozhodujúci vplyv na priebeh zjazdu mal D. Manuilskij, ktorý navrhol vedenie strany zložené primárne z predstavitel'ov l'avice. I ked' Manuilského menovania do funkcií KSČ znamenali zásadný obrat v politickom profile strany, boli bez odporu akceptované. Významnou zmenou bola strata mocenského postavenia B. Šmerala. Ten síce nebol odvolaný z politického byra, ale rozhodujúci vplyv v orgánoch strany získala l’avica. ${ }^{59}$

Disciplína vynútená Manuilským po jeho odchode erodovala. Naoktrojované l'avicové vedenie strácalo vplyv v strane a KSČ sa stala opä-

\footnotetext{
56 „Ovocie zlého činu Šmeralovho sa dostavuje. Z osobnej ctibažnosti robil stranu našu... Lež taktika, ktorú používal proti nám pomstí sa teraz jemu samému ... dochádza teraz k uznášaniu rezolúcií na župných konferenciách komunistov, v ktorých Šmeralovi sa vyslovuje nedôvera a tento, či priamo, či nepriamo, vyhlasovaný je za zradcu." Verčík kontra Šmeral. In: Robotnícke noviny, 28. 9. 1924, č. 223.

57 KRÁL, Václav: Cesta k leninizmu. Prameny k dějinám KSČ v letech 1921 - 1929. Praha : Academia, 1971, s. 128.

58 KRÁL, V.: Cesta k leninizmu..., s. 142. Podrobnú reakciu D. Manuilského na Šmeralov referát pozri: Význam diskusie v komunistickej strane Československa. O reči súdruha Šmerala. In: Pravda chudoby, 25. 10. 1924, č. 128; 29. 10.1924, č. 130; 31. 10. 1924, č. 131.

${ }^{59}$ Nech už sa v Šmeralovej mysli odohrávalo čokol'vek, rešpekt k autorite Kominterny zvít'azil a prehru v plnom rozsahu akceptoval. V súlade so svojim presvedčením však prehlásil: „Nevyvodzujeme z toho dôsledky, nehovoríme o demisiách, a ked' ako menšinu nás zavolajú pracovat', tak súdruhom z opozície podáme pri spoločnej práci naozaj priatel'skú ruku. Mám však obavy o jedno, a o to prosím súdruhov, ktorí preberajú zodpovednost': nepodceňujte dôležitost' masovej strany!"In: GALANDAUER, J.: Bohumír Šmeral, s. 113.
} 
tovne dejiskom frakčných bojov. Už v januári 1925 averzia voči autoritatívnemu prístupu Kominterny, presadzovanému bez ohl'adu na situáciu v KSČ, prerástla do otvoreného odmietnutia oficiálneho programu ústredného výboru. Predmetom kritiky, ktorú organizoval J. Bubník, sa stalo aj zasahovanie Kominterny do personálnych záležitostí strany. ${ }^{60}$ Ústredný výbor KSČ obvinil Bubníka s podvratnej činnosti a vylúčil ho zo strany. To však vyvolalo vlnu protestov vo viacerých straníckych organizáciách. Rozhodnutie vylúčit’ Bubníka nepodporili ani Šmeral so Zápotockým. ${ }^{61}$ Je pochybné, že l'avica by dokázala získat' prevahu v KSČ bez pomoci Komunistickej internacionály. Tá v dňoch 21. marca 6. apríla 1925 iniciovala zasadnutie V. rozšíreného pléna, ktoré etablovalo komisiu zloženú zo zástupcov viacerých komunistických strán poverenú posúdit' existujúcu situáciu v KSČ. ${ }^{62}$

Potvrdenie správnosti vylúčenia Bubníka komisiou rozšíreného pléna Kominterny zmenilo pomer síl v KSČ. Šmeral, Zápotocký a Kreibich, ktorí pôvodne kritizovali postup l'avice sa neodvážili odporovat' rozhodnutiu kominternovskej komisie a - slovami J. Plevu - ,...otvorene priznali svoje chyby, ktoré spočívali v podceňovaní pravičiarskeho nebezpečenstva... Takto pravičiari stratili prevahu a československá delegácia vyslovila súhlas s uzneseniami V. rozšíreného pléna EKI o československej otázke."63

Definitívnou bodkou za pluralitou politických názorov v KSČ bol III. zjazd strany, ktorý sa konal 26. - 28. septembra 1925. Ciel'om zjazdu nebolo formulovat' nové smernice pre prácu KSČ, ale upevnit' kontrolu Kominterny a prehíbit' proces bol’ševizácie iniciovaný po II. zjazde stra-

\footnotetext{
60 „Počas drahotných demonštrácií v Prahe 10. a 15. februára sa ukázalo, že krajský sekretariát KSČ na čele s poslancom J. Bubníkom otvorene sabotoval prípravu a uskutočnenie demonštrácií. Ústredný výbor strany získal súčasne dokument o tom, že poslanec J. Bubník už niekol'ko mesiacov organizoval v strane frakčnú činnost', tajne pripravoval rozkol v strane a pre svoje zámery získal prívržencov medzi rôznymi oportunistickými živlami v ostatných krajoch KSČ...Na frakčnej porade svojich prívržencov v Prahe koncom januára 1925 vyslovil sa proti línii Ústredného výboru a proti vedeniu Komunistickej internacionály." In: PLEVA, J.: Príspevok k dejinám..., s. 87.

${ }^{61} \mathrm{~V}$ súlade $\mathrm{s}$ marxisticko-leninskou terminológiou komentoval situáciu v KSČ Firsov: „Oportunistické elementy v brněnské, kladenské a některých dalších stranických organizacích vystoupily proti tomuto řešení. Menšina v ÚV KSČ (B. Šmeral, A. Zápotocký a někteří další), která podcenila nebezpečí pravicového oportunismu, nepodpořila levicovou většinu ústredního výboru a obvinila ji z nesprávného postupu. Vypukla ostrá vnitrostranická krize." In: FIRSOV, Fridrich Igorovič: Pomoc Kominterny při bolševizaci KSČ. Praha : Nakladatelství svoboda, 1988, s. 102 - 103.

62 „Komise vyslechla referáty představitelů ústředního výboru a také vystoupení členů delegací KSČ. Nejprve predstavitelé menšiny v ÚV KSČ, včetně B. Šmerala, A. Zápotockého, K. Kreibicha, ostře vystoupili proti ,levé většině a činili ÚV KSČ odpovědným za krizi ve straně." Plénum EKI sa však priklonilo na stranu l’avice a prehlásilo vylúčenie Bubníka za oprávnené. In: FIRSOV, F. I.: Pomoc Kominterny..., s. 103, 107.
}

${ }^{63}$ PLEVA, J.: Príspevok k dejinám..., s. 97. 
Podiel Bohumíra Šmerala na formovaní Komunistickej strany Československa...

ny. Predseda KSČ Josef Haken priznal, že cesta k bol’ševizácii nebola l'ahká a že len v pevnej jednote s Kominternou bude komunistická strana schopná odolat' „,bielemu teroru v Československu“.64

Predstavitelia Kominterny, vzhl'adom na Šmeralovu popularitu medzi členmi strany, nepovažovali za vhodné trestat’ jeho „chyby“ vylúčením zo strany. Postoj Kominterny k Šmeralovi definoval Lev Trockij, ktorý prehlásil, že vzhl'adom na dôveru značnej časti členov KSČ k Šmeralovi by bolo rizikom ho exemplárne potrestat'. ${ }^{65}$ Naopak, Šmeral bol zvolený do Ústredného výboru a do Politického byra strany a bezvýhradne akceptoval inštrukcie Kominterny bez ohl'adu na reálnu situáciu robotníckeho hnutia v republike. V prejave prednesenom na zjazde vyzdvihol rozhodujúci význam pomoci Komunistickej internacionály pri prekonávaní krízy v ČSR. ${ }^{66}$

Šmeralov konformizmus nemal na jeho postavenie v KSČ hlbší význam. Do bojov o mocenské pozície v strane, ktoré sa odohrávali v období po III. zjazde KSČ už nezasahoval. Pasívne znášal aj necitlivé presadzovanie bol’ševizácie proti vôli väčšiny členov strany. Šmeralovo sklamanie muselo byt' o to väčšie, že v dôsledku bol'ševizácie sa KSČ ocitla v situácii, ktorej sa obával a pred ktorou opakovane varoval - straty masovej členskej základne. ${ }^{67}$ V procese bol'ševizácie KSČ nebolo vo vedení strany pre Šmerala miesto. Vzhl'adom na jeho oddanost' sovietskemu Rusku a Kominterne, vedenie organizácie zvolilo diplomatickú formu odsunu B. Šmerala z rozhodovania o politikom smerovaní KSČ.

0 jeho d'alšom osude rozhodlo rozšírené plenárne zasadnutie Exekutívy Komunistickej internacionály na jar 1926. Šmeral, ktorý sa zasadnutia zúčastnil bol zvolený do vedúcich orgánov Kominternu. I ked z formálneho hl'adiska vol'bu možno interpretovat' ako vyjadrenie uznania za preukázané zásluhy, v praxi znamenala vynútený odchod z ČSR a ukončenie jeho pôsobenia v komunistickej strane. ${ }^{68}$ Ako priznal Šmeralov životopisec Jan Galandauer „od roku 1926 až do konca života vedie B. Šmeral doslova ,st'ahovavý život ... úlohy, ktoré mu ukladala Kominter-

\footnotetext{
${ }^{64}$ BRADÁČ, Z.: Boj za bolševizaci KSČ..., s. 273.

${ }^{65}$ RUPNIK, J.: Dějiny Komunistické strany Československa..., s. 74.

${ }^{66}$ GALANDAUER, J.: Bohumír Šmeral, s. 115.

${ }^{67}$ Podl'a historika P. E. Zinnera, počet členov strany mal permanentne klesajúcu tendenciu. V tridsiatych rokoch nepresiahol 75000 registrovaných členov. ZINNER, P. E.: Communist strategy..., s. 60 .

68 „Jednou z hlavních opor Kominterny ve vztahu ke KSČ byla stálá delegace teto strany v Moskvě. Vybraní činitele byli posílání do Moskvy na školení v aparátu Kominterny nebo $v$ Leninově škole. Tím se připravovala ideologická homogenizace Kominterny. Představitel, který strávil ve škole několik let, se vracel do vlasti zcela odř́znout od nové domácí reality a většinou se stával vykonavatelem záměrů Kominterny v místním vedení." In: RUPNIK, J.: Dějiny Komunistické strany Československa..., s. 60.
} 
na, ho zaviedli do najrozličnejších častí sveta - do Berlína, Paríža, Bruselu, d'alekého Mongolska a mnohých d'alších štátov. Československý komunista Šmeral sa stal profesionálnym revolucionárom a taký bol celý jeho d'alší život - jeho charakter a rytmus neurčovali jeho osobné, či rodinné záujmy a želania, ale potreby medzinárodného komunistického hnutia. "69

Presvedčenie o nesprávnosti mechanického prenášania sovietskych skúseností do KSČ Šmeral dokázal potlačit’ a plnil príkazy Komunistickej internacionály bez ohl'adu na vlastný názor až do svojej smrti 8. mája 1941 v Moskve.

${ }^{69}$ GALANDAUER, J.: Bohumír Šmeral, s. 118. 